\title{
Mathematics Teachers and Digital Technology: A Quest for Teachers' Professional Development in Indonesia
}

\author{
Kamirsyah Wahyu ${ }^{1)}$, Dwi Ratnasari' ${ }^{2)}$, Sofyan Mahfudy ${ }^{1)}$, Desventri Etmy ${ }^{2)}$ \\ ${ }^{1}$ Universitas Islam Negeri Mataram \\ ${ }^{2}$ STMIK Bumigora Mataram \\ Corresponding author: kwahyu@uinmataram.ac.id
}

\begin{abstract}
This article aims to explore a possible criterion of digital technology mathematics teachers' professional development ${ }^{1}$. The criterion was canvassed through qualitative exploratory study which involve a hybrid model of DigiTech TPD, online published articles of related TPD, and theoretical perspective which relate to digital technology in mathematics education. Related frameworks (Drijverset al, 2010; Trocki \& Hollebrands, 2018) and content analysis were utilized to analyze the first two data. Theoretical perspectives of digital technology in mathematics education were accounted to reflect prior data and explore the criterion. We found that the current TPD $^{2}$ has not developed the knowledge of task design and supported teachers' roles in orchestrating technology-rich mathematics teaching as seen in the low level of tasks and teachers' orchestration in the classroom. Related articles on TPD in Indonesia show that the programs have not touched decisive factors of successfully implementing digital technology. An alternative criterion for DigiTech TPD is explored which includes three aspects namely theoretical approach, model and content. It could be alternative point of departure for designing and conducting DigiTech TPD in Indonesia.
\end{abstract}

Keywords:Digital technology, GeoGebra, Teachers professional development, Mathematics teachers

Received: $12^{\text {th }}$ January 2019, Revised: $21^{\text {st }}$ January 2019, Accepted: $29^{\text {th }}$ January 2019

\section{Introduction}

The design, the role of teacher, and educational context are essential factors for the success of digital technology in mathematics education (Drijvers, 2015). Within the three factors, the roles played by mathematics teachers are very central. The teachers do not only orchestrate technology-rich mathematics teaching to which they differ substantially from paper and pencil teaching but also prepare digital technology, design corresponding task, and activities, and manage educational contexts such as students' motivation and assessment. To accomplish the roles, the teachers should have the mathematical knowledge, knowledge about the artifact, didactic knowledge of mathematics, and

\footnotetext{
${ }^{1}$ Digital technology mathematics teachers' professional development is abbreviated as DigiTech TPD

${ }^{2}$ Current TPD refer to the DigiTech TPD the authors have conducted
} 
didactic knowledge about the artifact (Tapan, 2003). Mishra and Koehler (2009) summarizeknowledge the teachers should possess in teaching mathematics with or through technology as TPACK (Technological pedagogical and content knowledge). Meanwhile, Leung (2017) proposes Mathematics Digital Task Design Knowledge (MDTDK) as the intersection of four knowledge domains, i.e., pedagogical knowledge, mathematics content knowledge, digital technology knowledge and knowledge about the artifact used.

Teachers are vital to students' opportunities to learn mathematics (Leong, Kaur, \& Kwon, 2017) in with or without digital technology classroom. In addition, Leong, Kaur, and Kwon (2017) argued that what mathematics teachers know and do is the result of their experiences both prior and after entering the profession as the teacher. Thus, mathematics teacher education and professional development are the points where the teachers begin for their roles in teaching mathematics in general and integrating digital technology in specific. Drijvers (2015) noted that to orchestrate mathematics learning with digital technology, a process of professional development is required which includes teachers own instrumental genesis or development of technological and pedagogical knowledge. The question is how mathematics teacher education and teachers' professional development contribute to the teachers' knowledge for the design of DigiTech $^{3}$ mathematics tasks and the orchestration of technology-rich mathematics teaching?

Mathematics teacher education is the place where the pre-service teachers begin to learn and develop an identity as future teachers. The policy and curriculum of teachers' education vary in each educational system and change over time in order to adjust the current need. Indonesia, for example, has gone through significant changes over a decade in pre-service education of mathematics teachers (Kusumah \& Nurhasanah, 2017). In the past ten years, the course of learning media in mathematics offered in Teachers Training Institutions (LPTK) for pre-service mathematics teachers was limited to physical tools. Nowadays, some LPTK (e.g., Jurusan Matematika UNY, 2014; Prodi Pendidikan Matematika UM, 2017) have offered specific course relating to ICT or digital technologyin mathematics teaching as a compulsory or optional course. For example, elearning course aims to have students design and implement e-learning in a task-based mathematics teaching (Prodi Pendidikan Matematika UNESA, 2016). However, as far as our concern, we have not found any online published works which examine the effectivity of the given course for mathematics teachers to design and implement related mathematics tasks and activities in the technology-rich mathematics classroom.

Teachers' professional development in mathematics education has been a concern of research worldwide (Leong, et al., 2017) for some important reasons, i.e., the quality of the teachers and its impacts on educational practices. One of the factors that determine the quality of teachers is their continuous professional development (Mullis, Martin, Foy, \& Arora, 2012). Prior researches (e.g., Liang, Zhang, Huang, Shi, \& Qiao, 2015; Unal, Demir, \& Kilic, 2011) have proved that teachers professional development relate to increased students' achievement and performances. However, Merliza and Retnawati (2018) found that the majority of in-service mathematics teachers were less involved in continuous professional development (CPD) activities either in person or learning community. Although some long-term TPD programs such as PMRI and Lesson Study(Kusumah \& Nurhasanah, 2017) and ELPSA (Lowrie \& Patahuddin, 2015) have been conducted, not all mathematics teachers could access the programs due to a large number of mathematics teachers in Indonesia.

${ }^{3}$ Digital technology is abbreviated as DigiTech 
In a specific digital technology professional development for in-service mathematics teachers, we have identified some types of TPD programs in Indonesia. Firstly, TPD is conducted by the Institute for Mathematics Teachers Training (P4TKMatematika, http://p4tkmatematika.org) annually or collaboration of LPTK and related parties such as Educational Institute of Quality Assurance (LPMP). This is categorized as top-down types (Kusumah \& Nurhasanah, 2017). Secondly, TPD which has been conducting by a group of researches tentatively as part of community service programs or research (Dhoruri, Sugiyono, Retnowati, Lestari, \& Sari, 2018; Koswara, Yuliawati, \& Rosita, 2017; Ratnasari, Wahyu, \& Mahfudy, 2018), including the TPD program held by the authors. This is referred to as bottom-up (Kusumah \& Nurhasanah, 2017). This TPD often involve local Working Group of Teachers (MGMP). Thirdly, TPD which is conducted by MGMP itself. Generally, digital technology is electronic tools, systems, devices and resources that generate, store or process data (Digipubs, 2018). In the context of mathematics education, digital technologies used by the teachers or researchers in the classroomand professional development are varied but mostly include the design and use of tasks in the instruction such as interactive geometry software (GeoGebra).

For the first and third type of TPD, we have not found any related scholary publication, e.g., journal articles or official reports which discuss and disseminate findings of the programs. The second type of TPD relatively has various online publications in the form of program reports stored in university e-repository and journal articles. However, most of the TPD programs only have training or workshop session without classroom teaching as the follow up (e.g., Dhoruri, et al., 2018) and not addressed the design as one of three decisive and crucial factors in digital technology integration in mathematics teaching (Drijvers, 2015). In addition the content of TPD, the publications are to explain how the TPD took place at the site. Thus, it is yet known and welldocumented how the TPD programs contribute to the mathematics teachers' related knowledge to orchestrate technology-rich mathematics classroom. The question "what is a possible criterion of a digital technology related TPD in Indonesian context?" is needed to be explored. We mean criterion here as to how to run TPD for digital technology which develops mathematics teachers related knowledge (e.g., MDTDK) and support their orchestration of technology-rich mathematics teaching.

A limited number of published works online regarding mathematics TPD which deal with the knowledge of digital technology mathematics task design in Indonesia indicate several worth-noting cases. Firstly, scholarly discourse and communication through online published works regarding the topic are deficient. Secondly, the lack of TPD which concern on the topic. Thirdly, the first and second cases cause fewer insights on the model of TPD for Indonesian context on digital technology. We believe that many related TPD has been held overseas and general TPD for in-service mathematics teachers in Indonesia. For digital technology, we could draw from the existing model (e.g., Lavicza, Hohenwarter, Jones, \& Dawes, 2006; Thurm, Klinger, \& Barzel, 2015; Verhoef, Coenders, Pieters, van Smaalen, \& Tall, 2015) but we still need the local context or characteristics (e.g., Ekawati \& Lin, 2014; Yusri, Goodwin, \& Mooney, 2015). These worth-noting cases as the standing point, this article seeks to explore a possible criterion of DigiTech TPD for in-service mathematics teachers through the TPD we conducted, related TPD in Indonesia and theoretical perspectives of digital technology task design and classroom orchestration. We use the term 'a possible criterion' to indicate that the criterion is alternative perspective or not 'a final criterion.' It enables further investigations on the criterion for developing mathematics teachers' knowledge of designing DigiTech mathematics tasks and supporting teachers' roles in the orchestration of technology-rich mathematics teachings. 


\section{Research Methods}

The current study aimed to explore a possible criterion of DigiTech TPD in Indonesian context which has not been widely discussed through online publications and implemented in the related TPD. The criterion we explored is not a conclusive criterion in which it will require further study. The criterion also help the mathematics educators when designing DigiTech TPD for in-service mathematics teachers in Indonesia. For these characteristics, the study we conducted can be categorized as qualitative exploratory study (Reiter, 2017; Stebbins, 2008).

In this study, we used three sources of data, i.e., a hybrid model of DigiTech TPD we have conducted, online published articles of related TPD, and theoretical perspectives which relate to digital technology task design and classroom orchestration. We extended the notion of within-case and cross-case analysis proposed by Merriam and Tisdell (2015) for this study. In within case analysis, each source of data was analyzed which refer to their characteristics. Teachers' design knowledge and classroom orchestration as the targeted data from TPD DigiTech we did were analyzed using the lens of Dynamic Geometry Tasks Analysis Framework (Trocki \& Hollebrands, 2018) and instrumental orchestration (Drijvers, Doorman, Boon, Reed, \& Gravemeijer, 2010). Content analysis was used to analyze online twenty articles on DigiTech TPD. It aims to categorize textual data into similar entities or conceptual category (Julien, 2008). Theoretical perspectives on digital technology in mathematics education were analyzed to determine the crucial factors in implementing technology-rich mathematics classroom. In cross-case analysis, we compare the results of three within-case analysis to explore a possible criterion for DigiTech TPD for in-service mathematics teachers in Indonesia. The elaboration of each data collection and analysis is presented respectively as follows.

\section{DigiTech TPD}

We held teachers' professional development program for in-service secondary mathematics teachers to introduce GeoGebra and DigiTech mathematics task. The teachers were mostly novice to the use of digital technology in mathematics teaching. The TPD was in the form of a two-day workshop and following by collaboration in class with the teachers. This type of TPD is called a hybrid model (Leong, et al., 2017). The first workshop involved 16 (sixteen) in-service mathematics teachers and two teachers worked with the authors in the classroom after the workshop. After that, we also had the second workshop with 11 (eleven) in-service mathematics teachers and classroom teaching with one teacher. The three teachers were involved in classroom teachings on a voluntary basis. The two-day workshop is sixteen hours training, about ten hours for GeoGebra and six hours for the design of DigiTech mathematics task. For GeoGebra, we focus on its features for geometry and transformation topics. In the design of DigiTech mathematics tasks, we introduced the nature of mathematics task in general and particularly DigiTech mathematics task. 'Investigating cyclic quadrilateral' was provided as the sample in the discussion (Leung, 2011). In the first phase, we discussed the design of DigiTech mathematics tasks then the teachers worked in a group in the first workshop and individual in the second workshop to design DigiTech mathematics task. Several groups and teachers presented their designed tasks to discuss together.

In this article, the mathematics tasks designed by teachers were analyzed through the lens of Dynamic Geometry Tasks Analysis Framework (Trocki \& Hollebrands, 2018). There are other frameworks proposed by mathematics education researchers (e.g., Fahlgren \& Brunström, 2014; Gustafsson, 2016; Leung, 2017) to examine the quality of DigiTech mathematics tasks. We decided to use the framework from Trocki and Hollebrands (2018) since it is specific to the tasks created from dynamic geometry software such as GeoGebra and relating mathematical dept with technological actions. 
Teachers' orchestration of the technology-rich mathematics classroom has been analyzed (Ratnasari, et al., 2018) through the framework of instrumental orchestration (Drijvers, et al., 2010) and didactics tetrahedron unfolded (Hollebrands \& Okumuş, 2018).

\section{Online published articles on DigiTech TPD}

We searched national scientific databases (Garuda, http://garuda.ristekdikti.go.id) and International reputable mathematics education journals published in Springer, JSTOR, and Elsevier to trace articles on DigiTech TPD for in-service mathematics teachers. The keywords used for the search in International database were teachers professional development, digital technology $/{ }^{4} I C T$, mathematics, Indonesia. Meanwhile, for the national database we used similar English keywords and some keywords in Bahasa namely pelatihan GeoGebra, GeoGebra, pelatihanteknologi/ICT/multimedia guru matematika. In the international database, we found just one related article (Patahuddin, 2013). In the national database, we had 52 documents, but none is relevant (keyword: teachers professional development), three relevant documents (keyword: pelatiban GeoGebra), 181 documents but none relates to TPD (keyword: GeoGebra), no document found for keyword pelatihanteknologi/ICT/multimedia guru matematika. We extended the search using a larger database (Google Scholar) with keywords pelatihanaplikasimatematikauntuk guru. We found many related articles but we randomly select twenty articles to be analyzed in this article (e.g., Dhoruri, et al., 2018; Koswara, et al., 2017). Two main questions led the content analysis, i.e., what is the content of the DigiTech TPD conducted by the authors? And what is the model of TPD? We mean content here is the aim of TPD, e.g., focus on digital tools or/and its classroom implementation. We refer the model of TPD to the summary of general TPD in mathematics education (Leong, et al., 2017)

\section{Theoretical perspectives}

There are lots of theoretical perspectives which relate to digital technology in mathematics education (Drijvers, Kieran, Mariotti, \& Ainley, 2010). In this article, we give more focus on theoretical perspectives which refer to DigiTech mathematics task design and teachers' orchestration of technology-rich mathematics teachings as two of three decisive factors of success implementation of digital technology in mathematics teachings (Drijvers, 2015). The question to lead the theoretical analysis was what knowledge the mathematics teachers should have to successfully implement digital technology in mathematics teachings?

\section{Results and Discussion}

In this part, we present and analyze the three data. DigiTech mathematics tasks designed by the mathematics teachers in the current TPD will be examined through the framework of Dynamic Geometry Tasks Analysis Framework (Trocki \& Hollebrands, 2018). It aims to reveal the teachers' knowledge of designing the task. Teachers' orchestration of technology-rich mathematics classroom which has been analyzed by Ratnasari et al. (2018) will be highlighted. These two cases are important to see the effect of TPD we have conducted and contribute to the idea of exploring possible criterion of DigiTech TPD for in-service mathematics teachers. Data from twenty online articles of related TPD in Indonesia which focus on revealing the content and mode of TPD will be explained. The result of this analysis is also used as the empirical background to support the explored criterion. At last, theoretical perspectives of digital technology in mathematics education will review the first two result of analyses and at the same time complement the criterion.

\footnotetext{
${ }^{4}$ Slash (/) sign means two keywords, digital technology or ICT
} 
Dynamic Geometry Tasks Analysis Framework (Trocki\& Hollebrands, 2018) divided DGS tasks into three levels, i.e., low, medium and high. The criterion for the level is the coordination of mathematical depts with technological actions. In the first workshop, the task was designed in the group, but in the second workshop it was as individual work. The variation was intended to see the difference between the results of the tasks. We had five group tasks and ten individual tasks. The results of analysis showed that all of the tasks are at the low level since they do not contain a collection of prompts that coordinate mathematical depth and technological actions (Trocki \& Hollebrands, 2018). In this article, we provided the excerpt of the analysis, one from group task and another from the individual task.

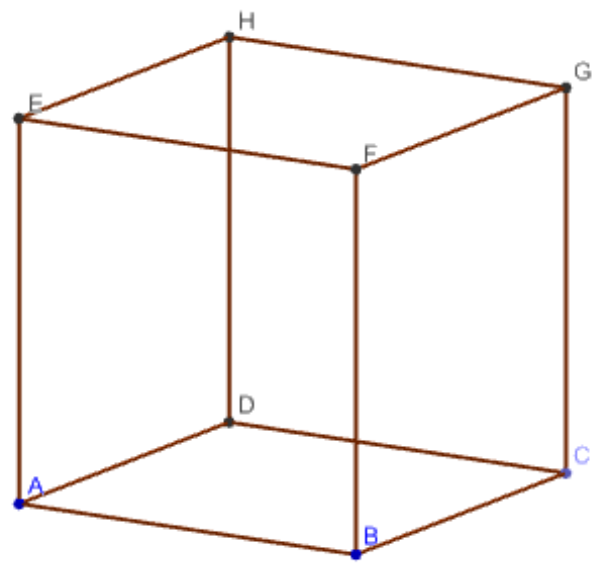

1. Draw a cube $A B C D$-EFGH

2. Construct a segment EG

3. Construct a projection of point $B$ on segment $E G$, e.g., $B^{\prime}$ which is the midpoint of $E G$

4. Measure the length of $B^{\prime} F$

5. Using the Pythagorean theorem, measure the segment $B B$ '

\section{Figure 1. Excerpt of analyzed individual DigiTech mathematics task ${ }^{5}$}

Figure 1 is a task designed by one of the teachers in the second workshop. It aims to lead students to understand and determine the distance of point B to the line EG. The task used students' constructed sketch. The cube is only for illustration in this article. Table 1 shows the analysis of the task. Trocki and Hollebrands (2018) defined prompt as "...a written question or direction related to a sketch that requires a verbal or written response. It may require a technological action, such as in the form of a drawing, construction, measurement or manipulation of a sketch...(p.14-15)"

Table 1. Coding summary of individual DigiTech mathematics tasks

\begin{tabular}{cc}
\hline Prompt number & $\begin{array}{c}\text { Task codes } \\
\text { (the coordination of mathematical dept } \\
\text { with technological actions) }\end{array}$ \\
\hline 1 & (N/A, A) \\
2 & N/A, C) \\
3 & N/A, C) \\
4 & $(\mathrm{~N} / \mathrm{A}, \mathrm{B})$ \\
5 & $(1, \mathrm{~N} / \mathrm{A})$ \\
\hline
\end{tabular}

${ }^{5}$ The original tasks were in Bahasa and translated in English for this article 


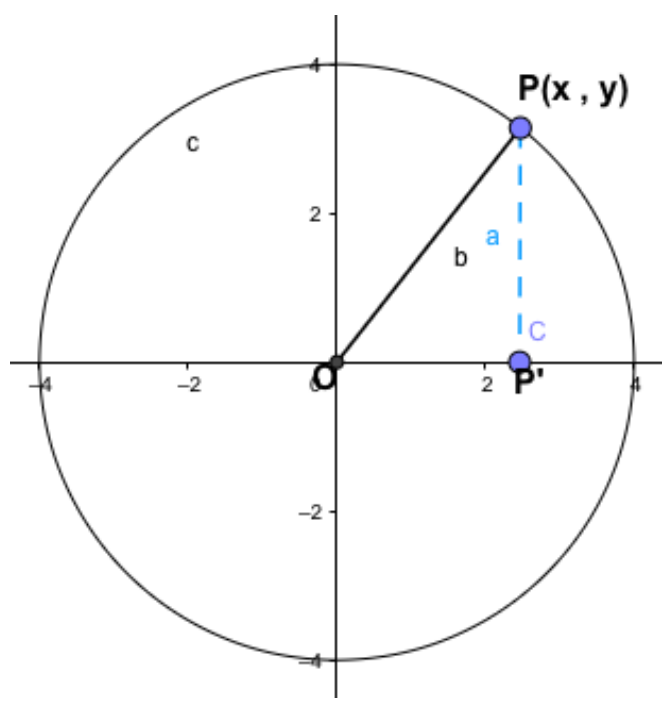

1. Draw a circle with origin $O(0,0)$

2. Draw point $P(x, y)$ on the circle

3. Construct a projection of point $P$ toward $x$-axes, name it $P^{\prime}$

4. Observe the triangle OPP' and measure $O P^{2}$ in $x$ and $y$

5. What is OP in the circle? What you can conclude?

\section{Figure 2. Excerpt of analyzed group DigiTech mathematics task}

Figure 2 is a task designed by teachers in the group in the first workshop. It aims to direct students formulate the circle equation with origin $\mathrm{O}(0,0)$. The task also used students' constructed sketch. The available figure is only for illustration in this article. Table 2 shows the analysis of the task.

Table 2. Coding summary of group DigiTech mathematics tasks Prompt number

Task codes

(the coordination of mathematical dept with technological actions)

\begin{tabular}{ll}
\hline 1 & $(\mathrm{~N} / \mathrm{A}, \mathrm{A})$ \\
2 & $(\mathrm{~N} / \mathrm{A}, \mathrm{A})$ \\
3 & $(\mathrm{~N} / \mathrm{A}, \mathrm{C})$ \\
4 & $(1, \mathrm{~N} / \mathrm{A})$ \\
5 & $(2, \mathrm{~N} / \mathrm{A})$ \\
\hline
\end{tabular}

The two tasks (Figure 1, Figure 2) are categorized as low-level tasks since each prompt has only mathematical dept or technological actions. The mathematical dept does not require a higher level of cognitive demand (Stein \& Smith, 1998), as prompt 3-5 developed in the framework. The technological actions range within drawing, measurement, and construction. Dragging or use of other dynamic aspects of the sketch and manipulation of the sketch has not included in the tasks.

Besides design of DigiTech mathematics tasks, teacher's roles also contribute to successful implementation of digital technology in mathematics education. Drijvers (2015) argue that the teachers have to orchestrate learning which exploit pedagogical potential of the tools and relate the experiences within technological experiences to paper and pencil skills or other mathematical activities. Ratnasari et al. (2018) observed teaching practices of two novice mathematics teachers in orchestrating technology-rich mathematics teaching. The teachers participated in the first workshop of DigiTech we conducted. It was found that the teachers' observed practices are mostly non-technology orchestrations, i.e., explanatory and board-instruction orchestration. It is a traditional setting of teaching where the teacher explains the task to the whole class (Drijvers, et al., 2014). The explanation has no apparent connection to the use of digital technology. The teachers brought almost the same routines to their technology classroom as their regular 
lesson in non-technology teaching. The use of digital technology in the observed teachers' practices did not transform or change mathematical activity.

In search of published works regarding the second type of DigiTech TPD, many related articles were found but we chose 20 (twenty) articles randomly which refer to the first ten pages of search results in Google Scholar. We think it is not feasible to list and filter all results of the search since over 12,600 documents then analyze the related articles. In this case, the twenty articles might not be representative to explain the content and model of DigiTechTPD. There might be one or more articles which addressed different content and model of TPD as in the analyzed articles. However, referring to the sites where the TPD were conducted, i.e., several representing cities such as Semarang, Lampung, Jember, Palembang, Aceh, Depok, Tabanan, so forth., we think the articles could provide the insights on TPD held in different places in Indonesia.

We then analyzed the content and model of TPD in the articles. The content is about the knowledge that would be developed through the programs. If it is knowledge about the technology or the tool, then the program concern on technical aspects of the tool. The model refers to how is the TPD conducted. Is it a workshop/training only or following by classroom teaching? We refer to the model of TPD summarized by Leong, et al. (2017), i.e., cascade and hybrid model. Of the twenty published works (journal articles), the content of TPD concern on the use of the digital tools to create learning media or sources for classroom teaching (e.g., Hapsari, Alamsyah, \& Awaludin, 2018; Koswara, et al., 2017) and none of TPD drawn from cascade and hybrid model. The TPD was only training which typically consists of several activities; the instructor trains the teachers to use the digital tool, the teachers practice the tools, and simulation or presentation for classroom teaching. The examples of learning media in the context of TPD are cubes constructed in GSP, learning sources stored in Moodle or worksheet in GeoGebra. Dynamic geometry software is mostly used in TPD $(70 \%)$. The other tools are Maple, Social Media Apps (Edmodo), Moodle and Mobile (Android). The sample of TPD articles shows that the DigiTech TPD for in-service mathematics teachers conducted by a group of lecturers as part of their community service or researches have not 'touched' three crucial content, i.e., the design of the task, teachers' role in orchestrating technology-rich mathematics teaching, and classroom teaching with the teacher.

Up to this part, we have analyzed the level of teachers' designed task in two workshops of the current TPD, highlighted the teachers' classroom orchestration in teaching mathematics with/through digital tools (Ratnasari, et al., 2018), and analyzed twenty articles related to DigiTech TPD in Indonesia. We have several important notes as follows. Firstly, although the content of the workshop of current TPD has concerned on DigiTech mathematics tasks, the workshop has not developed teachers' knowledge of design. It can be seen through the quality of the designed tasks by the teachers individually or in the group. Secondly, teachers' orchestration in classroom teaching using GeoGebra is still influenced by their old-classroom practices (Ratnasari, et al., 2018) which also show that the workshop has not supported teachers' orchestration of technology-rich classroom practices. Thirdly, DigiTech TPD conducted in Indonesia (e.g., Hapsari, Alamsyah, \& Awaludin, 2018; Koswara, et al., 2017) concern on the use of the digital tools to create learning media or sources for classroom teaching and were in the form of training without collaboration in the classroom teaching.

Regarding the current TPD, we identified two factors as the reason for the limitation, i.e., time allocation for the workshop and feedback in classroom teaching with the teachers. The two-day workshop is not enough to develop the teachers' knowledge of design and initiate the changes of classroom practices from without-technology to with technology. Moreover, the mathematics teachers involved in the workshop were the 
novice in the use of digital tools such as GeoGebra. More intense discussion and demos of teaching practices using the DigiTech mathematics designed tasks are required in the workshop/training to at least orientate the teachers to the new classroom practices with technology. For the DigiTech TPD reported in the twenty articles, possible factors such as funding, time constraints, and unknown of related theoretical frameworks might be the reasons why they did not address teachers' knowledge of task design, classroom orchestration, and a hybrid or cascade model of TPD.

We now call back the question "what is a possible criterion of a digital technology related TPD in Indonesian context?" and present theoretical perspectives which lead the way to the criterion. However, we argue that no single criterion which fit all condition. In case of DigiTech TPD, mathematics teachers as input in the TPD significantly determine the result of TPD. In specific, teachers' experiences in the design and use of mathematics tasks and the use of digital tools are two of many factors which contribute to TPD. We present three cases in this threoretical perspective namelydecisive factors in the use of digital technology in mathematics teaching (Drijvers, 2015), models of TPD (e.g., Leong, et al., 2017) and relevant theories of digital technology in mathematics education (Drijvers, et al., 2010; Drijvers, et al., 2014).

From the dept analysis of six prior researches, Drijvers (2015) identified three crucial and decisive factors which promote or hinder the the implementation of digital technology in mathematics education, i.e., design, teacher's role and educational context. The design refers to design of digital technology, design of corresponding task and activities and design of lesson and teaching in general. The three designs are interrelated. The use of digital technology in mathematics teaching did not decrease the roles of teachers. Moreover, the roles are getting 'complicated' since the teachers have to bring together the mathematics and the digital tools in the classroom practices. Drijvers (2015) argued that the teachers have to orchestrate mathematics learning which explore the pedagogical potentials of the digital tools, synthesize the technology-rich mathematical activities and relating the activities to the board or paper pencil based mathematical activities. Education context relates to the the implementation of digital technology in natural way, deal with student's motivation and engagement and the case of assessment. In the case of TPD, design of DigiTech mathematics tasks and teacher's roles in orchestrating mathematics teaching are a compulsory content since the teachers in teachers education have not adequally achieve them.

There are several theoretical perspectives which guide the use of digital technology in mathematics teaching (Drijvers, et al., 2010). In this article, we present the theories which relate to design of the task and classroom orchestration. For the first case, there are three proposed frameworks: (1) epsitemic model of task design in dynamic geometry environment (Leung, 2011) which he revised to Mathematics Digital Task Design Knowledge (Leung, 2017); (2) a model of task design which focus on exploration, explanation and generalization (Fahlgren \& Brunström, 2014); and (3) Dynamic Geometry Tasks Analysis Framework (Trocki \& Hollebrands, 2018). For the second case, instrumental orchestration (Drijvers, et al., 2010) and structuring features of classroom practices (Bozkurt \& Ruthven, 2015; Ruthven, 2009) have used to examine how mathematics teachers orchestrate technology-rich mathematics teachings.

Leong, Kaur, and Kwon (2017) summarized the characteristics of mathematics teachers' professional development in five Asian countries (India, Korea, Pakistan, Singapore and Taiwan) in case of sites, model, and key attributes. There are two models of professional development (PD) namely hybrid and cascade model. In a hybrid model of $\mathrm{PD}$, experts share or co-construct knowledge with teachers who integrate the knowledge into their classroom practices either simultaneously or after class. Meanwhile, a cascade model consists of a training portion of workshops conducted by the university 
scholars, followed by collaboration with the teachers in their classrooms, and finally teachers in the PD program developing fellow teachers in their school who were not in the PD program (Kumar \& Subramaniam, 2017).

We have highlighted theoretical perspectives regarding the decisive factors in successfully implementing digital technology in mathematics education, models of TPD and relevant theories of DigiTech mathematics tasks design and classroom orchestration. Additionally, we have revealed the limitation of the current TPD and other DigiTech TPD conducted in Indonesia. The following paragraphs will explore the possible criterion of DigiTech TPD in Indonesia drawn from the limitation of TPD we have conducted, analysis of articles which report the TPD and theoretical perspectives.

We argue that the DigiTech TPD for in-service mathematics teachers should mainly aims to develop teachers' knowledge of designing DigiTech mathematics tasks and their roles in orchestrating the use of digital technology in mathematics teaching. There are three elements to be considered in the DigiTech TPD for in-service mathematics teachers, i.e., the theoretical approach to the professional development, model, and content. Lesson study (Fernandez \& Yoshida, 2012) and design research (Swan, 2014; Thurm, et al., 2015) could be the alternative for the theoretical approach. The first has been familiar with Indonesian mathematics teachers and widely implemented (Kusumah \& Nurhasanah, 2017).

We think the ideal model for TPD is cascade model since it consists of a training session (workshop) held by the university scholars, followed by classrooms teaching with teachers, and eventually, teachers involved in the TPD developing fellow teachers in their school who were not in the program. This could be a genesis for school-based teachers working group which disentangle the funding and inactivity problems in MGMP. The program could be directly supported and facilitated by the schools. This model fits with the top-down TPD because it involves many parties and more resources. The TPD which conducted by mathematics educators or a group of researchers through community service program is feasible to apply the hybrid model. It is not just training as we found in the TPD related articles but following by collaboration with the teachers in the classroom. The bottom-up type of TPD has wider coverage area and could directly involve MGMP.

The content of TPD should refer to the three crucial factors of successfully implementing technology in mathematics education, i.e., the design, roles of teachers and educational context (Drijvers, 2015). For the design of dynamic geometry mathematics task in specific, the frameworks developed by Trocki and Hollebrands (2018) or Leung (2017) is very resourceful to be used in developing teachers' design knowledge and examining the designed tasks. In case of teachers' roles in orchestrating technology-rich mathematics teaching, instrumental orchestration (Drijvers, Doorman, et al., 2010) describes observed teaching practices of implementing technology in the mathematics classroom. Also, the collaboration of mathematics educators and researchers with the teachers in classroom teaching will form collaborative learning or well-known as the community of practices (Wenger, 1998). For example, a combination of Lesson Study as theoretical approach, hybrid model, and a focus on task design and teachers' roles in classroom orchestration which employ related frameworks, i.e. Dynamic Geometry Tasks Analysis Framework (Trocki \& Hollebrands, 2018) or Techno Pedagogic Task Design (Leung, 2017), instrumental orchestration (Drijvers, et al., 2010) and potential of community of practice (Wenger, 1998) would be alternative combination for designing DigiTech TPD for in-service mathematics teachers. 


\section{Conclusion}

In this article, we describe mathematics teachers' designed DigiTech mathematics task, highlight teachers' orchestration of technology-rich mathematics practices, reveal the content and model of DigiTech TPD in Indonesia and present theoretical perspectives of digital technology in mathematics education. The DigiTech TPD we conducted has not developed teachers' knowledge of DigiTech mathematics tasks design as the tasks do not co-ordinate mathematical depts with technological actions (Trocki \& Hollebrands, 2018) and supported teachers' role in orchestrating technologyrich mathematics teaching (Ratnasari, et al., 2018). In search and analysis of related TPD online published works, we found that the existing DigiTech TPD for in-service mathematics teachers in Indonesia have not adopted hybrid or cascade model (Leong, et al., 2017)and addressed the decisive factors of successfully implementing digital technology in mathematics education, i.e., the design of tasks and teachers' orchestration of technology-rich mathematics teaching. The theoretical perspectives have proposed the model of PD, the ways of designing DigiTech mathematics tasks and the orchestration teachers should have in with-technology mathematics teachings. Drawing from the three cases, we explored possible criterion which comprises three elements in DigiTech TPD in Indonesia, that is the theoretical approach to the professional development, model, and content. A further review and field implementation are required to examine the criterion.

\section{Acknowledgment}

We want to express our gratitude to the Directorate of Research and Community Service Ministry of Research and Higher Education for funding year 2018 community service program in the form of short period teachers' professional development of mathematics teachers.

\section{Bibliography}

Bozkurt, G., \& Ruthven, K. (2015). Expert and novice teachers' classroom practices in a technological environment, 2319-2325. Retrieved from https://hal.archivesouvertes.fr/hal-01289245/

Dhoruri, A., Sugiyono, S., Retnowati, E., Lestari, D., \& Sari, E. R. (2018). Pelatihan penyusunan lembar kegiatan siswa (LKS) matematika berbantuan Geogebra. Jurnal Pengabdian Masyarakat MIPA Dan Pendidikan MIPA, 2(1), 9-14. Retrieved from https://journal.uny.ac.id/index.php/jpmmp/article/view/18688

Digipubs. (2018). Teaching with digital technology. Retrieved from https://www.education.vic.gov.au/school/teachers/teachingresources/digital/Pa ges/teach.aspx

Drijvers, P. (2015). Digital technology in mathematics education: Why it works (or doesn't). In Selected Regular Lectures from the 12th International Congress on Mathematical Education (pp. 135-151). Springer, Cham. https://doi.org/10.1007/978-3-31917187-6_8

Drijvers, P., Doorman, M., Boon, P., Reed, H., \& Gravemeijer, K. (2010). The teacher and the tool: Instrumental orchestrations in the technology-rich mathematics classroom. Educational Studies in Mathematics, 75(2), 213-234. https://doi.org/10.1007/s10649-010-9254-5

Drijvers, P., Kieran, C., Mariotti, M., \& Ainley, J. (2010). Integrating technology into mathematics education: Theoretical perspectives. In C. Hoyles \& J.-B. Lagrange (Eds.), Mathematics Education and Technology-Rethinking the Terrain (pp. 89-131). New York: Springer US. https://doi.org/10.1007/978-1-4419-0146-0

Drijvers, P., Tacoma, S., Besamusca, A., van den Heuvel, C., Doorman, M., \& Boon, P. 
(2014). Digital technology and mid-adopting teachers' professional development: A case study. In O. Robutti \& N. Sinclair (Eds.), The Mathematics Teacher in the Digital Era(pp. 189-212). Dordrecht: Springer. https://doi.org/10.1007/978-94007-4638-1_9

Ekawati, R., \& Lin, F. (2014). Designing teacher professional development for mathematics teaching with variation theory. JME, 5(2), 127-137.

Fahlgren, M., \& Brunström, M. (2014). A model for task design with focus on exploration, explanation, and generalization in a dynamic geometry environment. Technology, Knowledge and Learning, 19(3), 287-315. https://doi.org/10.1007/s10758-014-9213-9

Fernandez, C., \& Yoshida, M. (2012). Lesson study: A Japanese approach to improving mathematics teaching and learning. Routledge.

Gustafsson, P. (2016). Frameworks for task design and technology integration in the mathematics classroom. Mälardalen University. Retrieved from http://mdh.divaportal.org/smash/get/diva2:1033547/FULLTEXT03.pdf

Hapsari, A. T., Alamsyah, N., \& Awaludin, A. A. R. (2018). Pelatihan media interaktif dalam pembelajaran matematika menggunakan aplikasi Cabri 3D. UNES Journal of Community Service, 3(2), 70-75.

Hollebrands, K., \& Okumuş, S. (2018). Secondary mathematics teachers' instrumental integration in technology-rich geometry classrooms. Journal of Mathematical Behavior, 49, 82-94. https://doi.org/10.1016/j.jmathb.2017.10.003

Julien, H. (2008). Content analysis. In L. GIven (Ed.), The SAGE Encyclopedia of Qualitative Research Methods. Sage Thousand Oaks, CA.

Jurusan Matematika UNY. (2014). Kurikulum 2014 Program Studi Matematika. Retrieved from http://pendidikan-matematika.fmipa.uny.ac.id/sites/pendidikanmatematika.fmipa.uny.ac.id/files/KURIKULUM 2014 _ maT.pdf

Koswara, U., Yuliawati, T., \& Rosita, N. T. (2017). Pelatihan program GeoGebra bagi guru matematika SMP di kabupaten Sumedang. E-Dimas: Jurnal Pengabdian Kepada Masyarakat, 8(1). Retrieved from http://journal.upgris.ac.id/index.php/edimas/article/view/1376

Kumar, R. S., \& Subramaniam, K. (2017). Constraints and affordances in bringing about shifts in practice towards developing reasoning in mathematics: A case study. In B. Kaur, O. N. Kwon, \& Y. H. Leong (Eds.), Professional Development of Mathematics Teachers: An Asian Perspective (pp. 121-140). Singapore: Springer.

Kusumah, Y. S., \& Nurhasanah, F. (2017). The endless long-term program of mathematics teacher professional development in Indonesia. In B. Kaur, O. N. Kwon, Y.H. Leong (Eds.),Professional Development of Mathematics Teachers (pp. 3345). Singapore: Springer.

Lavicza, Z., Hohenwarter, M., Jones, K., \& Dawes, M. (2006). Establishing a professional development network around dynamic mathematics software in England. International Journal for Technology in Mathematics Education, 16(1), 37-42.

Leong, Y. H., Kaur, B., \& Kwon, O. N. (2017). Mathematics teacher professional development: An Asian perspective. In B. Kaur, O. N. Kwon, \& Y. H. Leong (Eds.), Professional Development of Mathematics Teachers: An Asian Perspective (pp. 97108). Singapore: Springer Science \& Business Media.

Leung, A. (2011). An epistemic model of task design in dynamic geometry environment. ZDM, 43(3), 325-336. https://doi.org/10.1007/s11858-011-0329-2

Leung, A. (2017a). Exploring techno-pedagogic task design in the mathematics classroom. In A. Leung \& A. Baccaglini-Frank (Eds.), Digital Technologies in Designing Mathematics Education Tasks (Vol. 8, pp. 3-16). Springer. https://doi.org/10.1007/978-3-319-43423-0_1 
Leung, A. (2017b). Exploring techno-pedagogic task design in the mathematics classroom boundary object. In Digital Technologies in Designing Mathematics Education Tasks (pp. 3-16). Switzerland: Springer. https://doi.org/10.1007/978-3-31943423-0

Leung, A., \& Baccaglini-Frank, A. (2017). Digital Technologies in Designing Mathematics Education Taskes (Vol. 8). Switzerland: Springer.

Liang, G., Zhang, Y., Huang, H., Shi, S., \& Qiao, Z. (2015). Professional development and student achievement: International evidence from the TIMSS data. Journal of Postdoctoral Research, 3(2), 17-31.

Lowrie, T., \& Patahuddin, S. M. (2015). ELPSA as a lesson design framework. Journal on Mathematics Education, 6(2), 1-15. Retrieved from http:// ejournal.unsri.ac.id/index.php/jme/article/view/2166

Merliza, P., \& Retnawati, H. (2018). Continuing professional development (CPD) for junior high school mathematics teachers: An evaluation study. Research and Evaluation in Education, 4(1), 79-93.

Merriam, S. B., \& Tisdell, E. J. (2015). Qualitative research: A guide to design and implementation (Fourth). San Fransisco: John Wiley \& Sons.

Mishra, P., \& Koehler, M. J. (2009). What is technological pedagogical content knowledge? . Contemporary Issues in Technology and Teacher Education, 9(1), 60-70.

Monaghan, J., \& Trouche, L. (2016). Tasks and digital tools. In J. Monaghan, L. Trouche, \& J. M. Borwein (Eds.), Tools and Mathematics (pp. 391-415). Switzerland: Springer.

Mullis, I. V. S., Martin, M. O., Foy, P., \& Arora, A. (2012). TIMSS 2011: International mathematics report. Chestnut Hill, MA: TIMSS \& PIRLS International Study Centre, Boston College.

Patahuddin, S. M. (2013). Mathematics teacher professional development in and through internet use: Reflections on an ethnographic study. Mathematics Education Research Journal, 25(4), 503-521. https://doi.org/10.1007/s13394-013-0084-5

Prodi Pendidikan Matematika UM. (2017). Kurikulum Program Studi Pendidikan Matematika. Retrieved from http://matematika.um.ac.id/kurikulum_pendidikan_matematika.html

Prodi Pendidikan Matematika UNESA. (2016). Struktur kurikulum tahun akademik 2016-2017 program studi S1 Pendidikan Matematika. Retrieved from https://siakad.unesa.ac.id/akademik/file_diskripsi_matkul/0172016S-1 P. MATEMATIKA_(1-40).pdf

Ratnasari, D., Wahyu, K., \& Mahfudy, S. (2018). Teachers' old-fashioned classroom practices: A pitfall on the use of digital technology in mathematics teachings. Beta: Jurnal Tadris Matematika, 11(2), 114-130.

Reiter, B. (2017). Theory and methodology of exploratory social science research. International Journal of Science and Research Methodology, 5(4), 129.

Ruthven, K. (2009). Towards a naturalistic conceptualisation of technology integration in classroom practice. Education \& Didactique, 3(1), 131-159.

Stebbins, R. A. (2008). Exploratory research. In L. Given (Ed.), The SAGE encyclopedia of qualitative research methods (pp. 327-329). Sage Thousand Oaks, CA.

Stein, M. K., \& Smith, M. S. (1998). Mathematical tasks as a framework for reflection: From research to practice. MatheMatics Teaching in the Middle School, 3(4), 268-275.

Swan, M. (2014). Design research in mathematics education. In S. Lerman (Ed.), Encyclopedia of Mathematics Education (pp. 148-152). Dordrecht: Springer.

Tapan, S. (2003). Integration of ICT in the teaching of mathematics in situations for treatment of difficulties in proving. In The 3rd Conference of the European Society for Research in Mathematics Education (CERME 3). Bellaria, Italy. 
Thurm, D., Klinger, M., \& Barzel, B. (2015). How to professionalize teachers to use technology in a meaningful way: Design research of a CPD program. In N. Amado \& S. Carreira (Eds.), Proceedings of the 12th International Conference on Technology in Mathematics Teaching (pp. 335-343). Faro, Portugal: Universidade do Algarve.

Trocki, A., \& Hollebrands, K. (2018). The development of a framework for assessing dynamic geometry task quality. Digital Experiences in Mathematics Education, (May), 1-29. https://doi.org/10.1007/s40751-018-0041-8

Unal, H., Demir, I., \& Kilic, S. (2011). Teachers' professional development and students' mathematics performance: Findings from TIMSS 2007. Procedia Social and Behavioral Sciences, 15, 3252-3257.

Verhoef, N. C., Coenders, F., Pieters, J. M., van Smaalen, D., \& Tall, D. O. (2015). Professional development through lesson study: teaching the derivative using GeoGebra. Professional Development in Education, 41(1), 109-126.

Wenger, E. (1998). Communities of practice: Learning, meaning, and identity. New York: Cambridge University Press.

Yusri, I. K., Goodwin, R., \& Mooney, C. (2015). Teachers and Mobile Learning Perception: Towards a Conceptual Model of Mobile Learning for Training. Procedia - Social and Behavioral Sciences, 176, 425-430. https://doi.org/10.1016/j.sbspro.2015.01.492 